\title{
Acute coronary syndromeの病態と治療 司会者のことば
}

\author{
司会竹下彰 \\ 司会山口 洋
}

冠状動脈硬化症の基本病変である洣腫斑アテ ローム・プラークの線維性被膜に亀裂が生じた り破綻が起こって, その部位に急性血栓を形成 し, 冠動脈内腔の突然閉塞あるいは高度の狭窄 を惹き起し，心筋梗塞や突然死に発展したり， あるいは不安定狭心症の症状を残す冠性冠血流 障害の病態を acute coronary syndrome (ACS) 急性冠症候群として認識するようになった。こ れは1992年Fusterが剖検例から，臨床病態と対 比して病理所見を検討し，その発生機序を提唱 したことによる.すでに心筋梗塞の剖検例の殆 どの症例に䋆腫の潰瘍性破壊に伴って血栓が存 在しているとした所見は1972年に米国NIHの W.C. Robertらが, 本邦でも1973年に九州大学 病理学教室の田中健蔵らによって報告されてい た、いずれにも共通する所見は，急性の血栓形 成と,それによる冠閉塞か高度な狭窄を生じる ことである。

問題は如何なる機序で血栓を形成するかであ る. Fusterらの説では，破緃を起こして血栓形 成の原因になるのは，軟い不安定なプラークで コレステロールエステルなど脂質成分が多く, それに伴うマクロファージやT細胞など炎症細 胞, さらには組織因子やアテローム表面の線維 性被膜の脆弱化, 菲薄化に関連する間質組織蛋 白の分解酵素マトリックスメタロプロテアーゼ

たけした あきら：九州大学冠動脈疾患治療部

やまぐち ひろし：順天堂大学循環器内科
(MMPs) とその作用阻止物質（TIMPs）との 不均衡化, さらにはアンジオテンシン変換酵素 (ACE)の出現など多彩な因子の作用が関与し, 終にフィブリン，トロンビンの内膜形成，血栓 形成に至るとされている，ACSを考える上で の大きな疑問は, 不安定プラークなら内腔狭窄 が50\%にも致らない小さなプラークでも破綻し て血栓形成を起こし, その頻度が全ACSの半 数以上を占めるとされることである. Fusterら は, 死亡した例, すなわち剖検例の所見から見 たものであり，造影で調べた臨床観察結果も， 発作直前のものではなく, 再造影間隔も数力月 から数年と長く, 発症機序を網羅した研究では ないので実際とは隔った結論と判断せざるを得 ないところがある．治療上臨床的に重要視する のは75〜80\%以上の内腔狭窄を生じたプラーク が, 何らかの機序（無論プラーク破綻も含む） で血栓形成を起こし閉塞ないし高度狭窄に発展 する場合がACSの主体を成すものでなくては, これ迄の臨床事実と治療適応基準にも矛盾して しまうことになるからである。

一方，プラークびらんも同じで急性期の因子 によって血栓形成を起こしACSの成因となっ ている，この場合は，血流の血管壁に与える shear stressやスパズム, さらに喫煙等によっ て血栓形成防御に働いている内皮細胞が障害さ れ，血小板付着が生じたり，あるいは内皮細胞 の欠損が生じれば血液成分が血管壁組織に直接 
触れることによって血栓形成が起こると説明さ れる. 全ACS成因の30〜40\%は，このプラー クびらんの上に血栓が生じるものであろう. 残 る数\%は, 頻度は少ないが急激な冠れん縮によ り冠血管壁内の血腫により長時間（30分以上） prolonged spasmとして内腔閉塞が持続し, 二 次的に冠血管内腔に血栓が形成される機序が ACSの成因として考えられる.

以上の機序と治療の詳細は, 本シンポジウム で各演者が述べているのでよく参照頂きたい。

特に, ACSの予防は, 先ず徹底してコレス テロールの減少（食生活, 抗高脂血症薬による 管理)，そして血栓形成を起り難くすべく（抗
血小板薬, ワルファリン抗凝固療法, 禁煙等) 管理することである.

また，ACSの起こってしまった急性期の治 療は, 急性心筋梗塞に対しては現在広く行われ ている血栓溶解療法, direct PTCAあるいはス テント留置等が有効とされるが, ACSでも不 安定狭心症に対しては診断基準も施設間で異な り，その治療法と成績もまちまちで未だ確定さ れたとは言えないものがある。

最近の血小板GP IIb/IIIa阻害薬の開発と普及 により急性期治療も一段と優れたものが期待さ れる. 